\title{
URBANI POTOCI - PRISTUPAČNA STANIŠTA ZA PROVEDBU EKOLOŠKIH ISTRAŽIVANJA U NASTAVI PRIRODE I BIOLOGIJE
}

\author{
Mirela Sertić Perić, Ines Radanović \\ Prirodoslovno-matematički fakultet Sveučilišta u Zagrebu, Biološki odsjek, Zagreb, Hrvatska \\ msertic@biol.pmf.hr
}

\begin{abstract}
SAŽETAK
Širenjem urbanih zona i povećanjem broja urbanog stanovništva, gradovi su postali najveći izvori onečišćenja. Suvremeni urbani sadržaji povećavaju kvalitetu života gradskog stanovništva, međutim mijenjaju prirodno stanje okoliša. Stoga se u suvremenoj biologiji počela isticati urbana ekologija - jedna od novijih disciplina presudna za urbanizam i urbanističko planiranje, koja omogućuje procjenu stanja okoliša u gradovima te provedbu sustavnog nadzora, u svrhu očuvanja i zaštite gradskih ekosustava, uključujući i urbane vodotoke. U ovom radu navodimo primjer istraživanja urbanih potoka u kojem se razmatraju razmjeri i moguće posljedice urbanih utjecaja na ekologiju vodenih ekosustava i koje može poslužiti kao osnova za objašnjavanje osnovnih ekoloških koncepata i sadržaja, kao što su struktura bioloških zajednica, hranidbene mreže, oligotrofija ili eutrofija, ekološka valencija i rasprostranjenost organizama, ekološka niša. Nadalje, povezivanjem tematike urbane ekologije $s$ problematikom ugroženosti vodnih resursa te korištenjem urbanih potoka kao modelnih staništa za istraživanje ekoloških tema (i usvajanje ekoloških koncepata) u nastavi Prirode i Biologije, učenike se (osim važnih ekoloških koncepata) upoznaje i sa suvremenom ideologijom „zelenog rasta“, „zelenih“ gradova, održivog razvoja, zaštite okoliša te regionalnog razvoja. Opisano istraživanje primjereno je za učenike viših razreda osnovne škole (Biologija 7 i 8) i/ili za učenike srednjih škola (u vidu kratkoročnog i/ili dugoročnog ekološkog istraživanja urbanih potoka u neposrednoj blizini škole i/ili životne sredine učenika), a može se prilagoditi i za učenike mlađeg uzrasta.Predstavljeno istraživanje uključuje istraživanje ekološkog stanja urbanih potoka kroz praćenje: (i) kakvoće vode (fizičko-kemijskih svojstava vode); (ii) sastava vodene faune koja čini osnovu hranidbenih lanaca u vodenim ekosustavima (bentoskih makrobeskralježnjaka i organizama obraštaja); (iii) dinamike transporta (nizvodnog otplavljivanja) organizama u urbanim vodotocima; (iv) biotičkog indeksa na osnovu primijećenih makrobeskralježnjaka kao informaciji o onečišćenju vodotoka. Važno je napomenuti da odabrane aktivnosti mogu biti primijenjene $u$ istraživanju osnovnih bioloških pokazatelja svih, a ne samo urbanih, vodenih ekosustava. $\mathrm{U}$ tom smislu, opisana metodologija može biti prilagođena i primijenjena za slična istraživanja ostalih tipova tekućica dostupnih učenicima. Pri provedbi aktivnosti, potiče se korištenje Priručnika za voditelje programa GLOBE, koji je dostupan na poveznici http://globe.pomsk.hr/prirucnik.htm, i kojim se već služi i više od stotinu hrvatskih škola uključenih u GLOBE mrežu, ali se predlažu i novije (kvantitativne) metode uzorkovanja makrobeskralježnjaka i organizama obraštaja, kao i pojednostavljeni ključevi za taksonomsku determinaciju organizama primjenjivi u nastavi Prirode i Biologije.
\end{abstract}

Ključne riječi: urbana ekologija, makrozoobentos, drift, Hessov uzorkivač, biotički indeks, ključevi za taksonomsku determinaciju

\section{UVOD}

Gotovo polovica svjetske populacije živi u urbanim područjima, a suvremeni trend urbanizacije prisutan je i u Hrvatskoj. S gotovo $70 \%$ gradskog stanovništva, Hrvatska se svrstava u umjereno urbanizirane zemlje, a najveća koncentracija stanovništva (18\%) i većine privrednih djelatnosti je u gradu Zagrebu (Državni zavod za statistiku Republike Hrvatske, 2012). Širenjem urbanih zona i povećanjem broja urbanog stanovništva, gradovi su postali najveći potrošači pitke vode i postojećih energetskih zaliha, ali i najveći izvori onečišćenja. U razdoblju suvremenih globalnih promjena, potencijalni izvori, kao i okolišni pokazatelji i posljedice onečišćenja u urbanim zonama su brojni. Uz problem gradske buke i zagađenja zraka i tla, najčešće se ističe problem pitkih voda, koji je ponajviše vezan uz preobrazbu, prenamjenu i potpuno zatrpavanje gradskih vodenih tokova, odnosno uz onečišćenje gradskih vodenih ekosustava (Paul i Meyer, 2001). 
Osim za piće, urbani vodotoci mogu primjerice poslužiti i za regulaciju gradske (mikro)klime, biogeokemijsko kruženje tvari i poljoprivredne djelatnosti u urbanim zonama te u sportskorekreacijske svrhe, odnosno za promociju zdravog načina života i prevenciju bolesti urbanog stanovništva (Millennium Ecosystem Assessment 2005). Također, urbani potoci mogu poslužiti i kao pristupačna staništa za provedbu ekoloških istraživanja u nastavi Prirode i Biologije. Dakle, „usluge“ urbanih vodenih ekosustava (engl. ecosystem services) su višestruke i mogu znatno utjecati na kakvoću života stanovništva u gradovima, uključujući i njegovu odgojnu i obrazovnu dimenziju. Povećanje obima urbanih sadržaja i kvalitete života gradskog stanovništva često mijenja prirodno stanje okoliša te u određenoj mjeri smanjuje kakvoću prirodnih resursa (Paul i Meyer, 2001). Stoga se u suvremenoj biologiji počela isticati urbana ekologija - jedna od novijih disciplina presudna za urbanizam i urbanističko planiranje, koja omogućuje procjenu stanja okoliša u gradovima te provedbu sustavnog nadzora, u svrhu očuvanja i zaštite gradskih ekosustava, uključujući i urbane vodotoke.

Do danas u Hrvatskoj nije često istraživano i praćeno u kojoj mjeri urbani činitelji utječu na strukturu i ekološku funkcionalnost urbanih vodenih ekosustava, odnosno na kakvoću voda i karakteristike/stabilnost životnih zajednica u urbanim vodotocima. Procjena sastava faune urbanih potoka, uz određivanje bioloških pokazatelja koji upućuju na razinu stresa u potočnim životnim zajednicama, daje jedinstven uvid o potencijalno štetnom djelovanju urbanih utjecaja na organizme koji su posredno ili neposredno vezani uz gradske vodene ekosustave, uključujući i ljude.

Povezivanjem tematike urbane ekologije s problematikom ugroženosti vodnih resursa te korištenjem urbanih potoka kao modelnih staništa za istraživanje ekoloških tema (i usvajanje ekoloških koncepata) u nastavi Prirode i Biologije, učenike se (osim važnih ekoloških koncepata) može upoznati sa suvremenom ideologijom „zelenog rasta“, „zelenih“ gradova, održivog razvoja, zaštite okoliša te regionalnog razvoja (Europska komisija, 2013). Dakle, provođenjem malih istraživačkih projekata učenika na urbanim potocima, ponajprije se stječe uvid u razmjere antropogenih pritisaka na životne zajednice slatkih voda i procjenu ekološkog stanja urbanih vodotoka. Rezultati takvih istraživanja potom mogu poslužiti kao temelj za raspravu o kvaliteti urbanog okoliša, kao i o utjecaju ljudi na prirodna staništa i urbani okoliš. Također, kroz provedbu malih istraživačkih projekata u urbanoj sredini i svom bliskom okruženju, učenici detaljnije upoznaju svoju životnu sredinu te razvijaju stav $i$ svijest o pojmu i značaju regionalnog identiteta, kao i o suvremenim trendovima poput „zelenog rasta" $\mathrm{i}$ urbane ekologije.

\section{Kako uklopiti istraživanje urbanih potoka u nastavu Prirode i Biologije?}

Kratkoročna i/ili dugoročna ekološka istraživanja urbanih potoka u neposrednoj blizini škole i/ili životne sredine učenika mogu se uklopiti u nastavu Prirode i Biologije u sklopu izvanučioničke nastave, odnosno u vidu malih (predmetnih) i/ili većih (školskih) istraživačkih projekata učenika. Ovdje je naveden primjer istraživanja urbanih potoka u kojem se razmatraju razmjeri i moguće posljedice urbanih utjecaja na ekologiju vodenih ekosustava i koje može poslužiti kao osnova za objašnjavanje osnovnih ekoloških koncepata i sadržaja, kao što su npr. struktura bioloških zajednica, hranidbene mreže, oligotrofija/eutrofija, ekološka valencija i rasprostranjenost organizama, ekološka niša i sl. (NCVVO, 2016). Uzimajući u obzir poveznicu između urbanog okoliša, antropogenog utjecaja i problematike ugroženosti vodnih resursa, putem opisanog istraživanja učenici se (osim važnih

Sertić Perić, M., Radanović, I. 2017. Urbani potoci - pristupačna staništa za provedbu ekoloških istraživanja u nastavi Prirode i Biologije. Educ. biol. 3, 1, 106-126. 
bioloških/ekoloških koncepata) upoznaju i s konceptom održivosti i razvoja te pojmovima „zelenog rasta“ i „zelenih“ gradova te zaštite okoliša (Europska komisija, 2013; NCVVO, 2016).

Opisano istraživanje primjereno je za učenike viših razreda osnovne škole (Biologija 7 i 8 ) i/ili za učenike srednjih škola, a uključuje istraživanje ekološkog stanja urbanih potoka kroz praćenje:

kakvoće vode (fizičko-kemijskih svojstava vode);

sastava vodene faune koja čini osnovu hranidbenih lanaca u vodenim ekosustavima (bentoskih makrobeskralježnjaka i organizama obraštaja);

dinamike transporta (nizvodnog otplavljivanja) organizama u urbanim vodotocima.

Važno je napomenuti da odabrane aktivnosti mogu biti primijenjene u istraživanju osnovnih bioloških pokazatelja svih, a ne samo urbanih, vodenih ekosustava. U tom smislu, opisana metodologija može biti prilagođena i primijenjena za slična istraživanja ostalih tipova tekućica dostupnih učenicima. Pri provedbi aktivnosti, potiče se korištenje Priručnika za voditelje programa GLOBE, koji je dostupan na poveznici http://globe.pomsk.hr/prirucnik.htm, i kojim se već služi i više od stotinu hrvatskih škola uključenih u GLOBE mrežu. GLOBE-mreža provodi redovita i kontinuirana učenička mjerenja i opažanja (atmosfere, vode, tla i pokrova) u neposrednom okolišu škole, a rezultati istraživanja se međusobno upotpunjuju i povezuju, čime se ostvaruje program cjelovitog praćenja stanja okoliša (GLOBE Hrvatska, 2016). Osim GLOBE metodologije, u ovom radu se predlažu i neke nove (kvantitativne) metode uzorkovanja makrobeskralježnjaka i organizama obraštaja, kao i pojednostavljeni ključevi za taksonomsku determinaciju organizama upotrebljivi u nastavi Prirode i Biologije.

\section{METODE}

\section{Planiranje istraživanja urbanih potoka}

Za istraživanje se odaberu različita mikrostaništa (postaje istraživanja) duž odabranih urbanih potoka, duž kojih su evidentni različiti „scenariji“ antropogenog utjecaja. Odaberu se:

mikrostaništa u području manje intenzivne antropogene aktivnosti (npr. u prirodnom tj. nekanaliziranom dijelu toka; zasjenjeni dio toka okružen drvećem i drugom drvenastom vegetacijom), koja će predstavljati REFERENTNE POSTAJE te

mikrostaništa izložena većim urbanim i antropogenim utjecajima (npr. u kanaliziranom dijelu toka; u blizini utjecaja domaćinstava, gusto naseljenih područja, prometnica, sportskorekreacijskih, poljoprivrednih, industrijskih, turističkih sadržaja i sl.), koja će predstavljati ANTROPOGENO-UTJECANE POSTAJE.

Dakle, vrlo je važno odabrati istraživačke postaje (mikrostaništa), koje će predstavljati referentne postaje („kontrolu“), tj. postaje koje podnose najmanji pritisak antropogenih aktivnosti, te postaje koje podnose pojačani urbani (antropogeni) utjecaj. Također, važno je predvidjeti dostatan broj replikata za svaki tip postaje, odnosno potrebno je odabrati barem po 2 referentne postaje te barem po 2 antropogeno-utjecane postaje (npr. po 2 postaje u blizini prometnica, industrije, bolnice, gradskih vrtova i sl.), kako bi se po provedbi istraživanja mogla provesti kvalitetna analiza prikupljenih podataka. Provedba istraživanja ekološkog stanja urbanih potoka predviđa aktivnosti predstavljene u tablici 1. Pri obradi podataka sakupljenih tijekom istraživanja mogu se izračunati brojnost $\mathrm{i}$ indeks biološke raznolikosti za pojedine skupine organizama te za cjelokupnu zajednicu svake istraživačke postaje, a može se odrediti i kakvoća vode na osnovu vrlo jednostavno primjenjivog biotičkog indeksa prema BMWP-ASPT metodi (Biological Monitoring Working Party-Average Score Per Taxon). Važan je dio analize podataka statistička obrada podataka koja će ovisiti o dobi učenika i njihovom razumijevanju statističkih metoda, ali je neophodno da se pri interpretaciji podataka koriste srednje vrijednosti, kako bi učenici naučili da se na osnovu jednog zabilježenog podatka ili malog broja 
podataka ne može donijeti vjerodostojan zaključak. Također se pri interpretaciji preporučuje korištenje postotnog udjela kako bi se jasnije izrazio i uočio trend raspodjele i utjecaja podataka brojnosti ili biomase organizama u potoku.

Tablica 1 Provedba istraživanja ekološkog stanja urbanih potoka

Istraživačke aktivnosti

\begin{tabular}{|l|}
\hline 1. Uzorkovanje i provođenje mjerenja na terenu \\
\hline 1.1. Uzorkovanje vode za naknadnu analizu u školi \\
\hline 1.2. Mjerenje fizikalno-kemijskih parametara u vodi na terenu \\
\hline 1.3. Uzorkovanje bentoskih makrobeskralježnjaka u potočnom bentosu \\
\hline 1.4. Uzorkovanje bentoskih makrobeskralježnjaka u stupcu vode (tzv. uzorkovanje drifta) \\
\hline 1.5. Uzorkovanje organizama obraštaja \\
\hline 2. Analiza uzoraka bentosa i obraštaja u školi \\
\hline 2.1. Taksonomska determinacija makrobeskralježnjaka u uzorcima bentosa i drifta \\
\hline 2.2. Taksonomska determinacija organizama obraštaja \\
\hline 3. Obrada rezultata istraživanja
\end{tabular}

\section{Uzorkovanje i provođenje mjerenja na terenu}

\subsection{Uzorkovanje vode za naknadnu analizu u školi}

Na svakoj istraživačkoj postaji prikupe se replikatni uzorci vode (najmanje 2 uzorka), koji će naknadno (u školi) biti podvrgnuti analizama fizikalno-kemijskih parametara (npr. koncentracije kisika, nitrata, nitrita) odgovarajućim metodama opisanima u Priručniku za voditelje programa GLOBE (Matoničkin Kepčija, 2008). Uzorci vode sakupljaju se ručno, u čiste plastične boce.

\subsection{Mjerenje fizikalno-kemijskih parametara u vodi na terenu}

Mjerenje nekoliko fizikalno-kemijskih parametara (npr. temperatura, električna vodljivost, $\mathrm{pH}$ ) provodi se izravno na terenu pomoću odgovarajućih terenskih mjernih uređaja i metoda opisanih u Priručniku za voditelje programa GLOBE (Matoničkin Kepčija, 2008).

\subsection{Uzorkovanje bentoskih makrobeskralježnjaka u potočnom bentosu}

Prilikom svakog izlaska na teren, na svakoj istraživačkoj postaji uzimaju se replikatni uzorci bentosa (tj. barem 2 uzorka bentoskih makrobeskralježnjaka i pridružene organske tvari) uporabom Hessovog uzorkivača površine $0,049 \mathrm{~m}^{2}$ (Slika 1), opremljenog mrežom promjera oka $200 \mu \mathrm{m}$, kojim se standardno vrši kvantitativno uzorkovanje bentosa $s$ različitih/reprezentativnih tipova mikrostaništa/supstrata u plitkim tekućicama (Hauer i Resh, 2006). Hessov uzorkivač je pogodan, jer omogućuje precizno kvantitativno uzorkovanje bentosa. U nedostatku profesionalnog Hessovog uzorkivača, može se izraditi zamjenski pomoću plastične vodovodne ili kanalizacijske cijevi većeg promjera i materijala koji se u kućanstvima koristi za izradu zastora (tzv. markizeta).

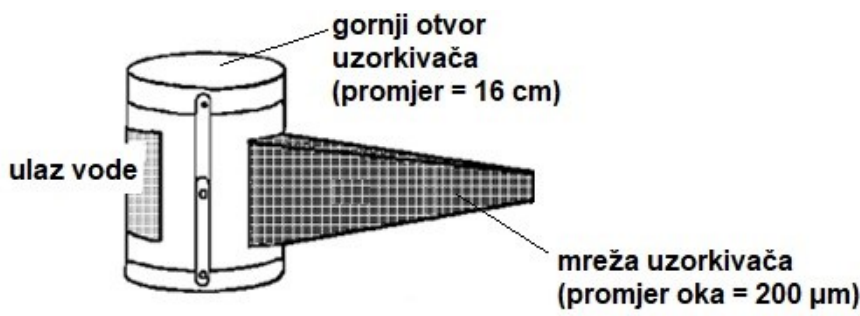

Slika 1 Hessov uzorkivač potočnog bentosa (prilagođeno prema: https://www.studyblue.com/notes/note/n/wildlife-exam3/deck/11017364)

Uzorkivač se uroni u potok te se kroz njegov gornji otvor rukom uznemiri dno potoka, čime se omogućuje ulazak organizama i tvari iz potočnog bentosa u mrežu uzorkivača (Slika 2a). Mreža uzorkivača se potom ispere (Slika 2b), a materijal prikupljen u mreži se pročisti pomoću sita istog

Sertić Perić, M., Radanović, I. 2017. Urbani potoci - pristupačna staništa za provedbu ekoloških istraživanja u nastavi Prirode i Biologije. Educ. biol. 3, 1, 106-126. 
promjera oka kao i mreža $(200 \mu \mathrm{m})$ i pohrani u $70 \%$ etanol. Budući da je mrežu potrebno isprati, kako bi se uklonio i pohranio prikupljeni materijal, pri dizajniranju uzorkivača je važno uzeti u obzir mogućnost pričvršćivanja i skidanja mreže s osnovne konstrukcije (cijevi) uzorkivača (Slika 2b).

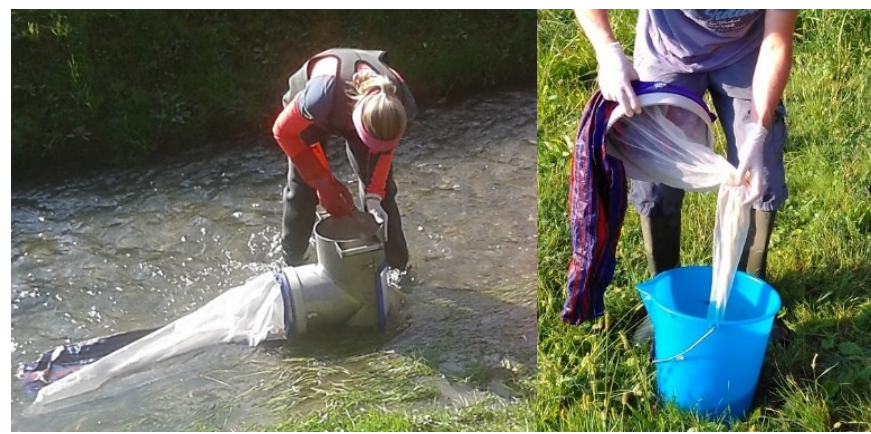

Slika 2 Uzorkovanje potočnog bentosa uporabom Hessovog uzorkivača (Foto: Z. Dragun)

\subsection{Uzorkovanje bentoskih makrobeskralježnjaka u stupcu vode (tzv. uzorkovanje drifta)}

Prilikom svakog izlaska na teren na svakoj istraživačkoj postaji uzorkuju se makrobeskralježnjaci i organska tvar u driftu (u transportu/stupcu vode) uporabom drift-mreže, odnosno cilindrične plastične cijevi (duljine $50 \mathrm{~cm}$, unutrašnjeg promjera $7,5 \mathrm{~cm}$; otvora $44,2 \mathrm{~cm}^{2}$ ) opremljene mrežom duljine 1,5 m (promjera oka $214 \mu \mathrm{m}$ ) (Slika 3). Mreža se može izraditi (sašiti) i od materijala markizeta (važno je prethodno pomoću mikroskopa i optičkog mikrometra odrediti promjer oka odabranog materijala).
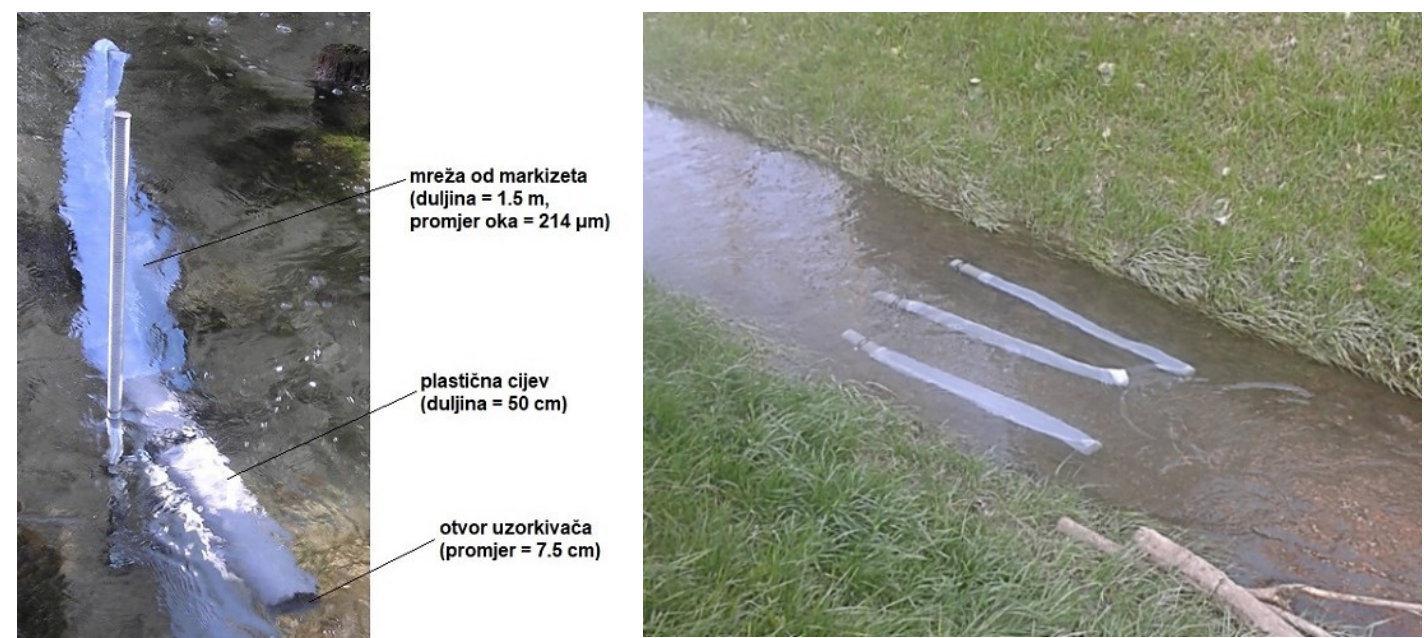

Slika 3 Drift uzorkivač uronjen u potok i prikaz simultanog prikupljanja uzoraka drifta. (Foto: M. Sertić Perić)

Na svakoj postaji, replikatni uzorci drifta (barem 2 uzorka) mogu se prikupljati simultano tijekom 1530 minuta (Slika 3). U cilju standardizacije varijabli drifta po jedinici volumena (broj jedinki $/ \mathrm{m}^{3}$, količina organske tvari $/ \mathrm{m}^{3}$ ), na otvoru svake drift mreže mjeri se brzina strujanja vode uporabom terenskog uređaja za mjerenje brzine strujanja vode (komercijalne inačice hidrometrijskog krila) te se zabilježi točno vremensko trajanje sakupljanja uzoraka (izloženost mreže struji vode). Prikupljeni uzorci drifta se isperu s mreža te pohrane u $70 \%$ etanol.

\subsection{Uzorkovanje organizama obraštaja}

Obraštaj se uzorkuje na svakoj postaji, tijekom svakog izlaska na teren, metodom struganja i četkanja ili pomoću korera (Slika 4), ovisno o tipu supstrata. S kamenite i drugih čvrstih podloga obraštaj se sastruže skalpelom ili četkicom (npr. četkicom za zube), a s pomične podloge (mulj, pijesak) korerom.

Sertić Perić, M., Radanović, I. 2017. Urbani potoci - pristupačna staništa za provedbu ekoloških istraživanja u nastavi Prirode i Biologije. Educ. biol. 3, 1, 106-126. 


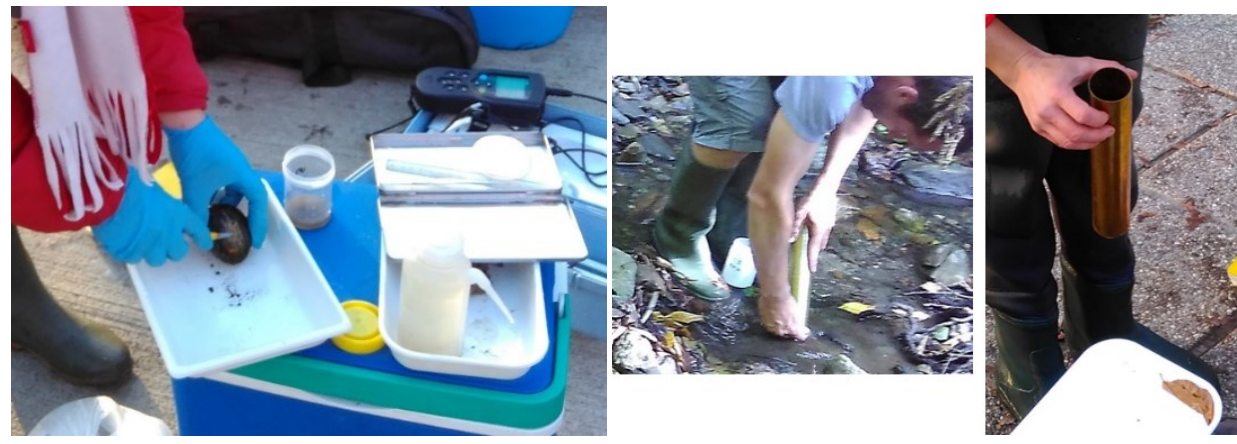

Slika 4 Uzorkovanje obraštaja metodom struganja i korerom (Foto: Z. Dragun)

Važno je zabilježiti površinu sastrugane podloge, odnosno ukupni volumen sastruganog ili korerom prikupljenog materijala, a prikupljeni materijal pohraniti u plastične bočice i dopremiti u školu na hladnom, bez konzerviranja, budući da se mora promatrati dok su organizmi još živi.

\section{Analiza uzoraka bentosa i obraštaja u školi}

Svi uzorci bentosa i obraštaja sakupljeni na terenu transportiraju se do škole, gdje se provodi njihova daljnja analiza:

2.1. Taksonomska determinacija makrobeskralježnjaka u uzorcima bentosa i drifta

U školi, iz svakog uzorka bentosa/drifta, izoliraju se i determiniraju makrobeskralježnjaci do najniže moguće taksonomske razine uporabom lupe i pojednostavljenih ključeva za taksonomsko određivanje slatkovodnih makrobeskralježnjaka (Prilog 1). Gustoća populacija pojedinih vrsta u bentosu izražava se kao broj jedinki po jedinici površine (broj jedinki $/ \mathrm{m}^{2}$ ), a gustoća drifta kao broj jedinki po jedinici volumena vode (broj jedinki $/ \mathrm{m}^{3}$ ), korištenjem sljedećih formula za izračunavanje:

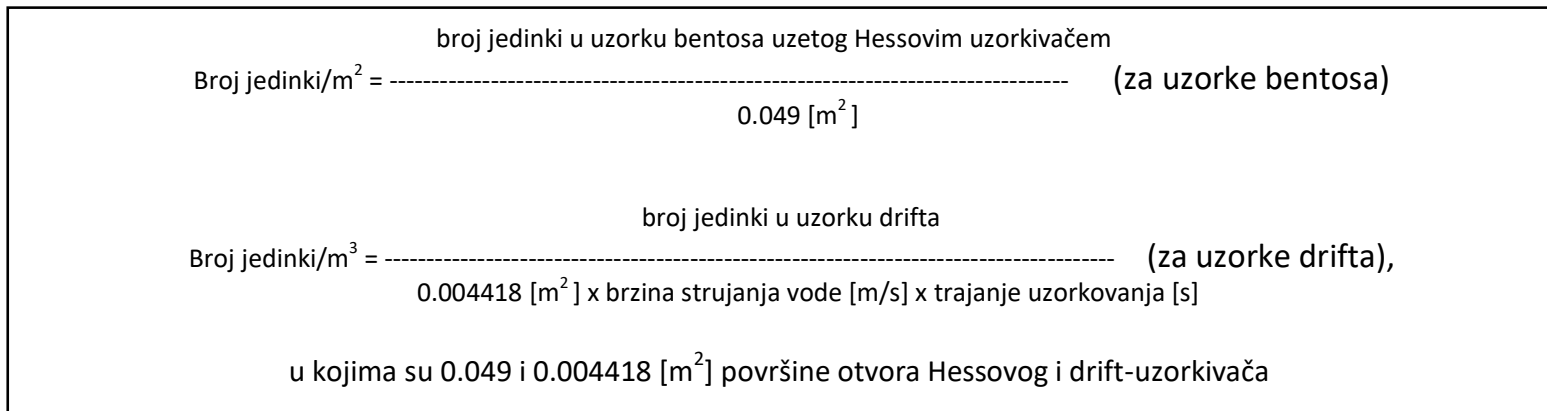

Prilikom taksonomske determinacije, svaka jedinka makrobeskralježnjaka može se dodatno i izmjeriti (u svrhu određivanja veličinskih kategorija organizama u bentosu i driftu) pomoću milimetarskog papira umetnutog ispod Petrijeve zdjelice u kojoj se determiniraju organizmi.

\subsection{Taksonomska determinacija organizama obraštaja}

Budući da je većina obraštajnih organizama osjetljiva na fiksative, uzorci obraštaja se pregledavaju na živom materijalu, najkasnije 24 sata nakon uzorkovanja, jer nakon toga dolazi do promjena u sastavu zajednice uslijed razmnožavanja, uginuća i začahurenja pojedinih vrsta. Uzorci se pregledavaju pomoću svjetlosnog mikroskopa i pojednostavljenih ključeva za taksonomsko određivanje slatkovodnih organizama obraštaja (Prilog 2). Za kvantitativnu analizu, uzorak se homogenizira protresanjem i Pasteurovom mikropipetom uzima se po 3 poduzorka volumena $0.5 \mathrm{~mL}$, u kojima se determinira i izbroji sva mikrofauna. Gustoća populacija pojedinih svojti izražava se kao broj jedinki po jedinici površine $\left(\right.$ jed. $\mathrm{cm}^{-2}$ ) ili volumena (jed. $\mathrm{cm}^{-3}$ ). 


\section{Obrada rezultata istraživanja}

3.1. Izračun brojnosti $i$ indeksa biološke raznolikosti za pojedine skupine organizama (makrobeskralježnjaci, organizmi obraštaja) te za cjelokupnu zajednicu svake istraživačke postaje/potoka metodi opisanoj u Priručniku za voditelje programa GLOBE (Matoničkin Kepčija, 2008).

3.2. Određivanje biotičkog indeksa kakvoće vode

Jedan od mogućih pokazatelja pri određivanju kvalitete vode je utvrđivanje biotičkog indeksa, koji može ukazati na onečišćenje u određenom području, a može se koristiti i kao metoda za kontinuirano praćenje kvalitete vode (biomonitoring). U radu $\mathrm{s}$ učenicima je primjereno koristiti biotički indeks prema BMWP-ASPT (Biological Monitoring Working Party-Average Score Per Taxon) metodi (Armitage i sur, 1983; Alba-Tercedor i sur, 1988; Martin i sur, 2007). Ta metoda kao indikatorske organizme koristi makrobeskralježnjake, najviše zastupljene kukcima koji dio ili cijeli životni ciklus provode u vodi. BMWP-ASPT metoda temelji se na načelu da različiti vodeni beskralježnjaci imaju različitu toleranciju na zagađivače te svrstava slatkovodne makrobeskralježnjake u skladu s njihovim sposobnostima da podnesu onečišćenje u njihovim staništima (tablica 2). U osnovi, taj indeks procjenjuje raznolikost organizama s obzirom na karakteristike specifične skupine i njene mogućnosti preživljavanja prema stupnju onečišćenja vodenog staništa (. Najveća prednost ove metode je jednostavnost za korištenje. Na osnovu promatranja potrebno je utvrditi postojanje pojedinih skupina kukaca i zabilježiti bodovnu vrijednost u skladu s tablicom 2. Zbroj bodova kao BMWP vrijednost ukazuje na kvalitetu vode, $s$ time da više vrijednosti (u rasponu od 1 do 13) ukazuju na manju razinu onečišćenja, odnosno na bolju kvalitetu vode (tablica 3). Zbroj bodova podijeli se s brojem zabilježenih skupina kako bi se izračunala ASPT vrijednost, koja odražava procjenu raznolikosti staništa. Za olakšano korištenje, posebno kod mlađih učenika, može se koristiti slikovni ključ za biotički indeks prema BMWPASPT metodi (prilog 4), pri čemu nije potrebno poznavanje latinskih imena skupina i porodica makrobeskralježnjaka. U svrhu određivanja BMWP-ASPT, makrobeskralježnjaci se mogu sakupiti Surberovom mrežom, Hessovim uzorkivačem (u plitkoj vodi) ili ručnom D-mrežom (Matoničkin Kepčija, 2008) kojom se skuplja uzorak tijekom 3 minute, pri čemu se ispred mreže uznemiruje dno vodenog staništa kako bi makrobeskralježnjaci koji ga nastanjuju bili uhvaćeni u mrežu (slika $5)$.

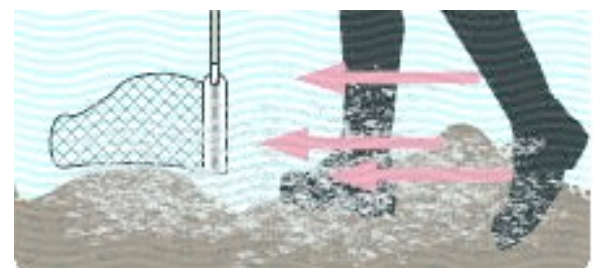

Slika 5 Sakupljanje uzoraka makrobeskralježnjaka u potoku ručnom D mrežom (prilagođeno prema Woodlands View Education 2017)

U sakupljenom uzorku odredi se broj vrsta makrobeskralježnjaka, a dovoljna je identifikacija na razini porodice ili skupine. Postupak identifikacije može se olakšati uporabom pojednostavljenog ključa za određivanje (Prilog 1). Dobiveni podaci o organizmima mogu se grupirati prema tablici 2 i/ili 4, pri čemu se svakoj razlikovanoj skupini makrobeskralježnjaka doda odgovarajuća bodovna vrijednost, a zbroj se iskazuje kao BMWP indeks. Ako se želi napraviti detaljnija analiza, ASPT kao srednja vrijednost izračuna se dijeljenjem zbroja bodova (BMWP) s brojem zabilježenih skupina na staništu.

Sertić Perić, M., Radanović, I. 2017. Urbani potoci - pristupačna staništa za provedbu ekoloških istraživanja u nastavi Prirode i Biologije. Educ. biol. 3, 1, 106-126. 
Tablica 2 Biotički indeks prema BMWP - ASPT metodi (revidirano slijedom prema Armitage i sur, 1983; Alba-Tercedor i Sanchez-Ortega, 1988; Martin i sur, 2007 uz dopunu podataka prema istraživačkom iskustvu u RH)

\begin{tabular}{|c|c|c|}
\hline \multicolumn{3}{|c|}{ BMWP tablica bodovnih vrijednosti } \\
\hline $\begin{array}{c}\text { Skupine } \\
\text { makrobeskralježnjaka }\end{array}$ & Porodice makrobeskralježnjaka & Vrijednost \\
\hline Plecoptera & Perlidae & 13 \\
\hline Plecoptera & Chloroperlidae & 12 \\
\hline Ephemeroptera & Siphlonuridae & 11 \\
\hline Plecoptera & Taeniopterygidae, Perlodidae & 11 \\
\hline Trichoptera & Philopotamidae, Odontoceridae & 11 \\
\hline Ephemeroptera & Heptageniidae, Ephemerellidae, Potamanthidae, Leptohyphidae & 10 \\
\hline Plecoptera & Leuctridae, Capniidae, Chloroperlidae & 10 \\
\hline Trichoptera & Phryganeidae, Goeridae, Lepidostomatidae & 10 \\
\hline Crustacea & Astacidae & 9 \\
\hline Ephemeroptera & Leptophlebiidae, Ephemeridae & 9 \\
\hline Plecoptera & Nemouridae & 9 \\
\hline Odonata & Cordulegasteridae & 9 \\
\hline Trichoptera & Polycentropodidae, Molannidae, Beraeidae, Brachycentridae, Sericostomatidae & 9 \\
\hline Ephemeroptera & Ephemerellidae, & 8 \\
\hline Odonata & Gomphidae, Corduliidae & 8 \\
\hline Coleoptera & Gyrinidae & 8 \\
\hline Trichoptera & Rhyacophilidae, Leptoceridae, Glossosomatidade, Philopotamidae & 8 \\
\hline Ephemeroptera & Caenidae & 7 \\
\hline Coleoptera & Scirtidae, Dryopidae & 7 \\
\hline Trichoptera & Psychomyiidae, Hydropsychidae, Hydroptilidae, Limnephilidae, Polycentropodidae & 7 \\
\hline Gastropoda & Viviparidae, Ancylidae & 6 \\
\hline Odonata & Coenagrionidae, Calopterygidae, Aeshnidae & 6 \\
\hline Coleoptera & Elmidae & 6 \\
\hline Diptera & Tipulidae, Simuliidae & 6 \\
\hline Bivalvia & Unionidae & 5 \\
\hline Hirudinea & Piscicolidae & 5 \\
\hline Crustacea & Gammaridae & 5 \\
\hline Ephemeroptera & Baetidae & 5 \\
\hline Odonata & Platycnemidae, Lestidae, Libellulidae & 5 \\
\hline Heteroptera & Hydrometridae, Gerridae & 5 \\
\hline Coleoptera & Dytiscidae, Hydrophilidae & 5 \\
\hline Megaloptera & Sialidae & 5 \\
\hline Turbellaria & Planariidae & 4 \\
\hline Gastropoda & Hydrobiidae & 4 \\
\hline Bivalvia & Sphaeriidae & 4 \\
\hline Oligochaeta & Enchytraeidae, Naididae & 4 \\
\hline Arachnida & Hydracarina & 4 \\
\hline Odonata & Coenagrionidae & 4 \\
\hline Heteroptera & Nepidae, Naucoridae, Notonectidae, Pleidae, Corixidae & 4 \\
\hline Megaloptera & Corydalidae & 4 \\
\hline Coleoptera & Haliplidae, Chrysomelidae, Curculionidae & 4 \\
\hline Diptera & $\begin{array}{l}\text { Chironomidae - Diamesinae, Prodiamesinae, Orthocladinae, Tanytarsini; Anthomyiidae, } \\
\text { Ceratopogonidae, Chaoboridae, Dixidae, Dolichopodidae, Empididae, Limoniidae, Psychodidae, } \\
\text { Stratiomyidae, Tabanidae }\end{array}$ & 4 \\
\hline Hirudinea & Piscicolidae & 4 \\
\hline Gastropoda & Valvatidae, Lymnaeidae, Physidae, Planorbidae & 3 \\
\hline Bivalvia & Sphaeriidae & 3 \\
\hline Hirudinea & Glossiphoniidae, Erpobdellidae & 3 \\
\hline Hemiptera & Belostomatidae, Corixidae, Naucoridae, Nepidae, Notonectidae, Pleidae, Veliidae & 3 \\
\hline Coleoptera & Hygrobiidae, Gyrinidae, Helodidae, Noteridae & 3 \\
\hline Gastropoda & Physidae & 2 \\
\hline Crustacea & Asellidae & 2 \\
\hline Diptera & Chironomidae - Chironomus, Tanypodinae; Culicidae, Ephydridae, Muscidae, Thaumaleidae & 2 \\
\hline Oligochaeta & Stylodrilus, Tubificidae & 1 \\
\hline Diptera & Sciomyzidae, Syrphidae, and Rhagionidae & 1 \\
\hline Lepidoptera & Crambidae, Pyralidae & 1 \\
\hline Hirudinea & Hirudididae & 0 \\
\hline
\end{tabular}

Sertić Perić, M., Radanović, I. 2017. Urbani potoci - pristupačna staništa za provedbu ekoloških istraživanja u nastavi Prirode i Biologije. Educ. biol. 3, 1, 106-126. 
Tablica 2 koristi se samo za riječne ekosustave ili za istraživanje lokvi i manjih barica uz potoke i rijeke. Uporabom tablice 2 rezultat biotičkog indeksa dobiva se kao prosjek bodova svih skupina organizama prisutnih u uzorku. Više vrijednosti (u rasponu od 1 do 13) ukazuju na manju razinu onečišćenja, odnosno na bolju kvalitetu vode.

Nije potrebno da učenici poznaju latinska imena organizama, ali ih se može ponuditi za izrazito zainteresirane učenike starije dobi. Biotički indeks kod najmlađih učenika može se izračunati i bez poznavanja naziva skupina makrobeskralježnjaka, na način da učenici koriste pri promatranju oznake broja skupine koju su redoslijedno uočili u skladu s vrijednosti organizama te skupine (skupina 1 , skupina 2 ...) za što im može pomoći slikovni ključ za izračunavanje biotičkog indeksa potoka (prilog 4).

Kombinacijom BMWP i ASPT vrijednosti vrši se procjena kvalitete, odnosno razina onečišćenja vodenog staništa (tablica 3 ).

Tablica 3 BMWP-ASPT vrijednosti za interpretaciju rezultata uz raznolikost makrobeskralježnjaka (prema Armitage i sur., 1983; Alba-Tercedor i Sanchez-Ortega,1988)

\begin{tabular}{|c|c|c|c|}
\hline $\begin{array}{l}\text { BMWP } \\
\text { vrijednost }\end{array}$ & $\begin{array}{c}\text { ASPT } \\
\text { vrijednost }\end{array}$ & $\begin{array}{l}\text { Kvaliteta i interpretacija } \\
\text { raznolikosti zajednice }\end{array}$ & Tumačenje za stanište s obzirom na antropogeni utjecaj \\
\hline$>150$ & $>6$ & vrlo dobro & vrlo čisto, nezagađeno ili bez utjecaja \\
\hline 101-150 & $>5$ & dobro & čisto ili neznatno promijenjeno \\
\hline $51-100$ & $>4$ & umjereno & prihvatljivo, ali prisutan manji utjecaj \\
\hline $16-50$ & $<4$ & loše (siromašno) & kritično uz umjereni utjecaj ili zagađenje \\
\hline 0-15 & & jako loše & jako onečišćeno \\
\hline \multicolumn{4}{|c|}{ BMWP = zbroj svih bodova za skupine zabilježene u uzorku / na postaji } \\
\hline \multicolumn{4}{|c|}{ ASTP = BMWP podijeljen s brojem skupina u uzorku / na postaji } \\
\hline
\end{tabular}

Voda se prema kakvoći može klasificirati i prema tablici 4 (Trihadiningrum and Tjondronegoro, 1998). Grupiranje se temelji na prisutnosti skupina koje se nalaze u specifičnoj grupi organizama koji podnose određeni stupanj zagađenja vode (tablica 4).

Tablica 4 Makrobeskralježnjaci kao indikatori zagađenja vode (prema Trihadiningrum and Tjondronegoro, 1998).

\begin{tabular}{|c|c|c|}
\hline \multicolumn{2}{|c|}{ Stupanj zagađenja } & Makro beskralježnjak kao indikator \\
\hline 1. & Nije zagađeno & Trichoptera (Sericosmatidae, Lepidosmatidae, Glossosomatidae); Planaria \\
\hline 2. & Dobra kvaliteta & $\begin{array}{c}\text { Plecoptera (Perlidae, Peleodidae); Ephemeroptera (Leptophlebiidae, Pseudocloeon, } \\
\text { Ecdynuridae, Caebidae); Trichoptera (Hydropschydae, Psychomydae); Odonata; Coleoptera } \\
\text { (Elminthidae) }\end{array}$ \\
\hline 3. & Malo zagađeno & $\begin{array}{l}\text { Mollusca (Pulmonata, Bivalvia); Crustacea (Gammaridae); Odonanta(Libellulidae, } \\
\text { Cordulidae); Hirudinea (Glossiphonidae, Hirudidae); Hemiptera }\end{array}$ \\
\hline 4. & Zagađeno & Oligochaeta (Tubificidae); Diptera (Chironomus thummi-plumosus); Syrphidae \\
\hline 5. & Jako zagađeno & nema makro beskralježnjaka \\
\hline
\end{tabular}

Analiza kakvoće vode na temelju tablice 4 može se kontrolirati i naputcima u tablici 5.

Tablica 5 Naputci za kontrolu i nadopunu određenja kakvoće vode prema tablici 4

\begin{tabular}{|c|c|c|}
\hline $\begin{array}{c}\text { Kakvoća vode } \\
\text { vrlo čisto } \\
\text { čisto }\end{array}$ & $\begin{array}{c}\text { Uamo Trichoptera i Planaria, bez indikatora vrsta klasa } 2 \text { - } 6 \\
\text { kombinacija pokazatelja organizama iz klasa 1, 2 i } 3\end{array}$ \\
\hline prihvatljivo & $\begin{array}{c}\text { kombinacija organizama indikatora iz klasa 2, 3 i } 4 \\
\text { kombinacija organizama indikatora iz klasa 3, 4 i } 5\end{array}$ \\
\hline Kritično onečišćeno & kombinacija indikatorskih organizama iz klasa 4 i 5 \\
\hline jako onečišćeno &
\end{tabular}

3.2. Statistička obrada podataka - analiza i usporedba razmjera utjecaja pojedinih antropogenih pritisaka među istraživačkim postajama/potocima

3.3. Dodatni problemski zadaci za učenike na osnovu rezultata istraživanja i s njima povezane literature kao i istraživanja drugih autora (npr. kreiranje sheme hranidbene mreže temeljene na

Sertić Perić, M., Radanović, I. 2017. Urbani potoci - pristupačna staništa za provedbu ekoloških istraživanja u nastavi Prirode i Biologije. Educ. biol. 3, 1, 106-126. 
organizmima pronađenima u uzorcima), koji bi učenike potakli na uočavanje, razmišljanje, zaključivanje i kreativnost i koji bi se temeljili na korelacijsko-integracijskom, istraživačkom i problemskom načinu poučavanja (Begić i sur, 2016).

\section{ZAKLUUČAK I METODIČKI ZNAČAJ}

Globalno je prepoznato da urbanizacija nije samo širenje gradova, već i širenje urbanog načina života i antropogenog utjecaja, koji se očituje u svim gradskim sadržajima pa tako i u školskim sadržajima unutar urbanih sredina.. Budući da do danas u Republici Hrvatskoj nije istraživano u kojoj mjeri širenje urbanog utjecaja utječe na kakvoću voda urbanih vodotoka i dinamiku pripadajućih životnih zajednica, predloženo istraživanje se oslanja na vrlo aktualnu i relevantnu temu u suvremenoj ekologiji. Kroz usporedbu urbanih potoka na nekoliko postaja duž njihovog toka, a koje podnose različiti stupanj i vrstu antropogenog utjecaja, predloženo istraživanje može pomoći učenicima u svladavanju osnovnih ekoloških koncepata i sadržaja, kao što su npr. struktura bioloških zajednica, hranidbene mreže, oligotrofija/eutrofija, ekološka valencija i rasprostranjenost organizama, ekološka niša i sl. Također, rezultati istraživanja mogu kod učenika potaknuti i razvoj kritičkog mišljenja, budući da temeljem rezulltata učenici mogu raspraviti o tome je li javna percepcija urbanih vodotoka istinita ili iskrivljena, odnosno jesu li urbani vodotoci uistinu „pustinje“ ili „vrela života“ usred gradova. Stoga, predloženo istraživanje ne obećava samo originalne i zanimljive podatke relevantne za urbanu ekologiju, već predstavlja i veliki korak naprijed za razvoj istraživačkog i problemskog načina poučavanja te promovira sudjelovanje javnosti (učenika, nastavnika, škola) u znanstvenim istraživanjima (tzv. „citizen science“). Postupnim uključivanjem većeg broja učenika, nastavnika i škola u slična istraživanja urbanih vodotoka/staništa diljem Hrvatske, omogućilo bi se stvaranje mreže "mladih istraživača" (učenika), njihovih mentora (nastavnika) i institucija (škola), koja bi doprinijela globalnim naporima u razotkrivanju značaja biološke raznolikosti i ekološkog statusa različitih staništa unutar urbanih ekosustava. Dodatna vrijednost ovoga rada jesu i prijedlozi novijih (kvantitativnih) metoda uzorkovanja makrobeskralježnjaka i organizama obraštaja, te pojednostavljenih ključeva za taksonomsku determinaciju slatkovodnih organizama (makrobeskralježnjaka i organizama obraštaja), koji bi se mogli upotrijebiti u nastavi Prirode i Biologije.

\section{LITERATURA}

Alba-Tercedor J., Sanchez-Ortega A. 1988. Um metodo rapido y simple para evaluarlacalidade biologica de las agua scorrientes basado em el de Hellawell (1978). Limnética, 4, 51-56.

Armitage, P. D., D. Moss, J. F. Wright \& M. T. Furse, 1983. The performance of a new biological waterquality score system based on macroinvertebrate sover a wide range of unpolluted running-water sites. Wat. Res. 17, 333-347

Begić, V., Bastić, M., Radanović, I. 2016. Utjecaj biološkog znanja učenika na rješavanje zadataka viših kognitivnih razina. Educatio biologiae, 2,13-42.

Državni zavod za statistiku Republike Hrvatske 2012. Statistički ljetopis Republike Hrvatske 2012. Državni zavod za statistiku $\mathrm{RH}$, Zagreb

Europska Komisija 2013. Nacrt zajedničkog izvješća o zapošljavanju uz Komunikaciju Komisije o godišnjem pregledu rasta za 2014. Europska Komisija, Bruxelles

GLOBE Hrvatska 2016. Priručnik za voditelje programa GLOBE, http://globe.pomsk.hr/GLOBEinfo.htm, preuzeto 27.6.2017.

Hawkes, H.A. 1997. Origin and Development of the Biological Monitoring Working Party Score System. Water Research, 32, 3, 964-968.

Hauer, F. R., Resh, V. H. 2006. Macroinvertebrates. U: Hauer F. R., Lamberti G. A. (ur.). Methods in Stream Ecology, pp. 435463, Academic Press, San Diego, USA

Martin, G., Veal, A., Guthrie, R., Murray-Bligh, J., O'Neill, I. 2007. Revision and testing of BMWP scores. SNIFFER, Centre for intelligent environmental systems, Edinburgh, http://www.envirobase.info/PDF/SNIFFER WFD72a.pdf, preuzeto 13.9.2014.

Matoničkin Kepčija, R.2008. Istraživanje vode. GLOBE Hrvatska, http://public.carnet.hr/globe/prirucnik/voda.PDF, preuzeto 27.6.2017.

Millennium Ecosystem Assessment 2005. Ecosystems and Human Well-Being: Synthesis. Island Press, Washington

Sertić Perić, M., Radanović, I. 2017. Urbani potoci - pristupačna staništa za provedbu ekoloških istraživanja u nastavi Prirode i Biologije. Educ. biol. 3, 1, 106-126. 
NCVVO 2016. Ispitni katalog za državnu maturu u školskoj godini 2016./2017. Biologija. Nacionalni centar za vanjsko vrednovanje obrazovanja, Zagreb

Paul, M. J., Meyer, J. L. 2001. Streams in the urban landscape. Annual Review of Ecology, Evolution, and Systematics, 32, 333-365.

Trihadiningrum, Y., Tjondronegoro, I. 1998. Bioindikator Pencemaran Badan Air Tawar di Indonesia: Siapakah Kita, Lingkungan \&.Pembangunan 18, 1, $45-60$.

\section{IZVORI ZA IZRADU SLIKOVNOG KLUČA}

AFF. 2012. Macro-invertebrate Identification. Alice Ferguson Foundation. http://fergusonfoundation.org/btw-students/macroinvertebrate-identification/, preuzeto 2.3.2017.

Bouchard, Jr., R. W. 2009. Guide to Aquatic Invertebrate Families of Mongolia. University of Minnesota. http://midge.cfans.umn.edu/sites/g/files/pua3236/f/media/06plecoptera.pdf, preuzeto 2.3.2017.

Bumblebee org 1997. Hexapoda - insects. Bumblebee org http://www.bumblebee.org/invertebrates/Hexapoda.htm, preuzeto 16.4.2014.

DeLorme, A. 2005. Digital key to aquatic insects of North Dakota. Valley City State University Macro-invertebrate lab, North Dakota Department of Health. http://www.waterbugkey.vcsu.edu/, preuzeto 2.3.2017.

Dobson, M. 2013. Family-level keys to freshwater fly (Diptera) larvae: a brief review and a key to European families avoiding use of mouthpart characters Freshwater Reviews, 6, 1-32, DOI: 10.1608/FRJ-6.1.450

D'Souza, K. 2015. Aquatic Invertebrate Identifications. BIObus. http://biobus.ca/aquatic-invertebrate-identification/, preuzeto 2.3.2017.

Elliott, J. M., Humpesch, U. H., Macan, T. T. 1988. Larvae of the British Ephemeroptera: a key with ecological notes. FBA Scientific Publication 49. http://dep.wv.gov/wwe/getinvolved/sos/documents/benthic/british mayflykey.pdf, preuzeto 2.3.2017.

Hawking, J., Smith, L., Le Busque, K., Davey, C. 2013. The MDFRC Bug Guide. Murray-Darling Basin Authority. http://www.mdfrc.org.au/bugguide/, preuzeto 2.3.2017.

Iowa State University. 2017. Identification, Images, \& Information for Insects, Spiders \& Their Kin for the United States \& Canada. lowa State University, Department of Entomology. https://bugguide.net, preuzeto 2.3.2017.

Kazlev, M. A. 2002. Palaeos - Life Through Deep Time. http://palaeos.com/metazoa/arthropoda/index.html, preuzeto 2.3.2017.

Kerovec, M. 1986. Priručnik za upoznavanje beskralješnjaka naših potoka i rijeka. SNL, Grafički zavod Hrvatske, Zagreb.

Kriska, G. 2013. Freshwater Invertebrates in Central Europe: A Field Guide. Springer Science \& Business Media, Wien.

Nilsson, A. 1996. Aquatic Insects of North Europe 1. Apollo Books, Stenstrup, 1-274.

Nilsson, A. 1997. Aquatic Insects of North Europe 2. Apollo Books, Stenstrup, 1-440.

Orma J. 2006. Mollusca. PNWFWG. Smith Museum of Natural History, http://www.stitchingnature.com/snails/Mollusca, preuzeto 2.3.2017.

Stroud Water Research Center. 2017. Macroinvertebrate Identification Key. Stroud Water Research Center. https://stroudcenter.org/macros/key/, preuzeto 2.3.2017.

Sundermann, A., Lohse, S., Beck, L.A., Haase, P. 2007. Key to the larval stages of aquatic true flies (Diptera), based on the operational taxa list for running waters in Germany, Annales de Limnologie - International Journal of Limnology, 114, DOI: $10.1051 / \mathrm{limn} / 2007028$.

Valley City State University. 2017. Digital Key to Aquatic Insects of North Dakota. Valley City State University Macroinvertebrate Lab. http://www.waterbugkey.vcsu.edu/php/mainkey.php, preuzeto 2.3.2017.

Vital Signs Program. 2017. Freshwater macroinvertebrates. Gulf of Maine Research Institute. http://vitalsignsme.org/macroinvertebrates, preuzeto 2.3.2017.

WWH. 2017. Diptera (Flies, Mosquitoes, Midges, Gnats) (Insects). The-Crankshaft Publishing. http://what-whenhow.com/insects/diptera-flies-mosquitoes-midges-gnats-insects/, preuzeto 2.3.2017.

WWP. 2016. A Guide to Freshwater Invertabrates of Ponds \& Streams in Malaysia. Water Watch Penang. http://waterwatchpenang.org/a-guide-to-freshwater-invertabrate/, preuzeto 2.3.2017. 
Prilog 1 Pojednostavljen ključ za taksonomsko određivanje slatkovodnih makrobeskralježnjaka (prilagođeno prema: http://www.naturalresources.sa.gov.au/adelaidemtloftyranges/about-us/our-regions-progress/monitoring-and-

evaluation/schools)
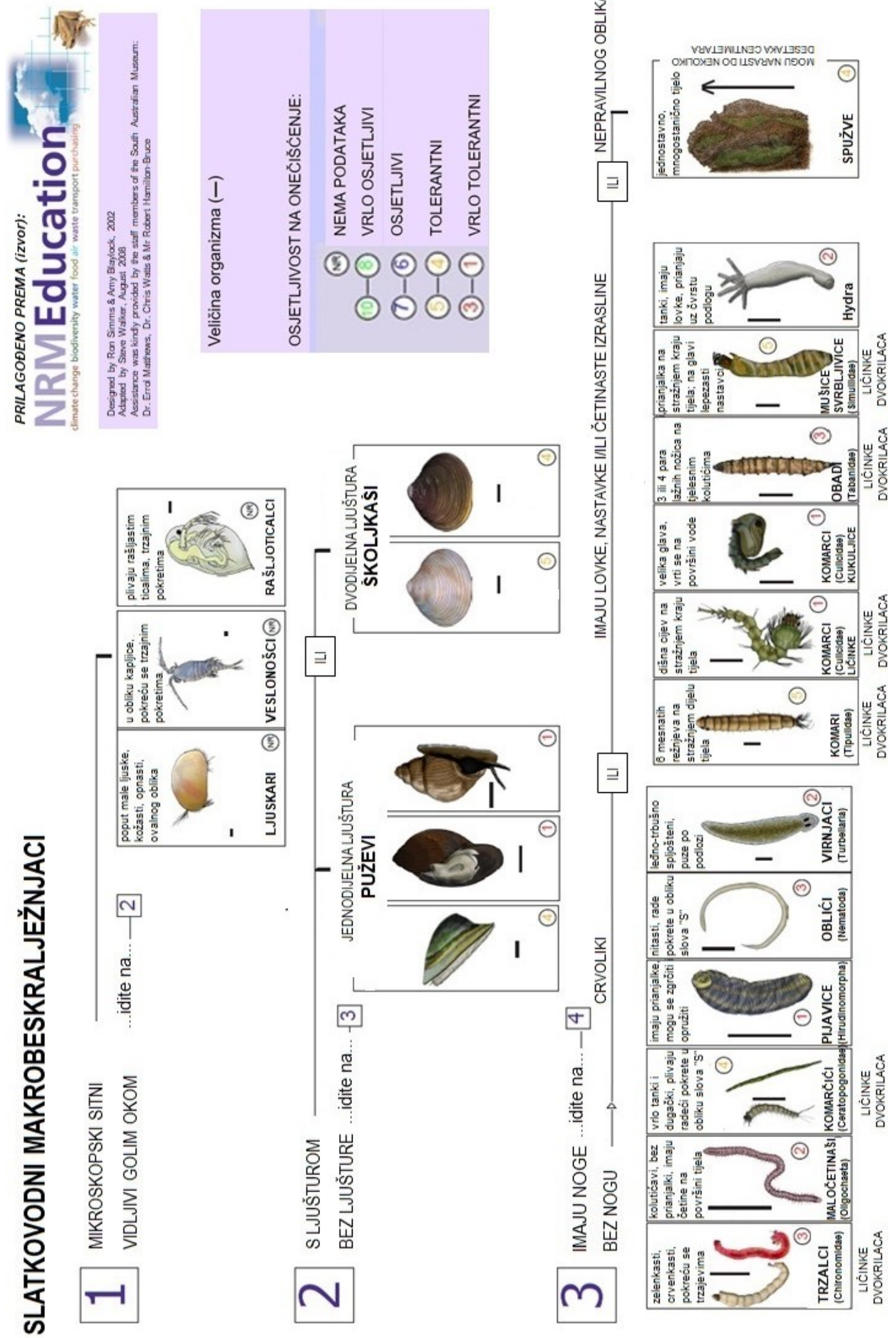

Sertić Perić, M., Radanović, I. 2017. Urbani potoci - pristupačna staništa za provedbu ekoloških istraživanja u nastavi Prirode i Biologije. Educ. biol. 3, 1, 106-126. 
Prilog 2 Pojednostavljen ključ za taksonomsko određivanje slatkovodnih makrobeskralježnjaka - nastavak

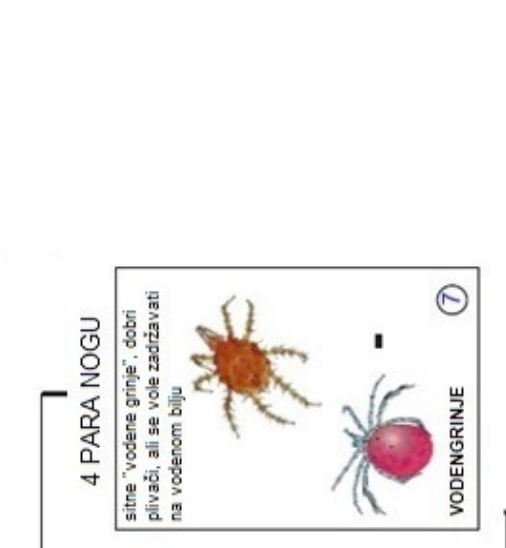

ㅍ

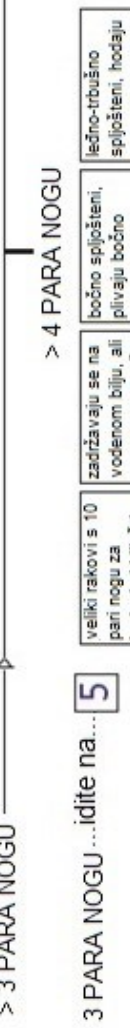

$\checkmark$
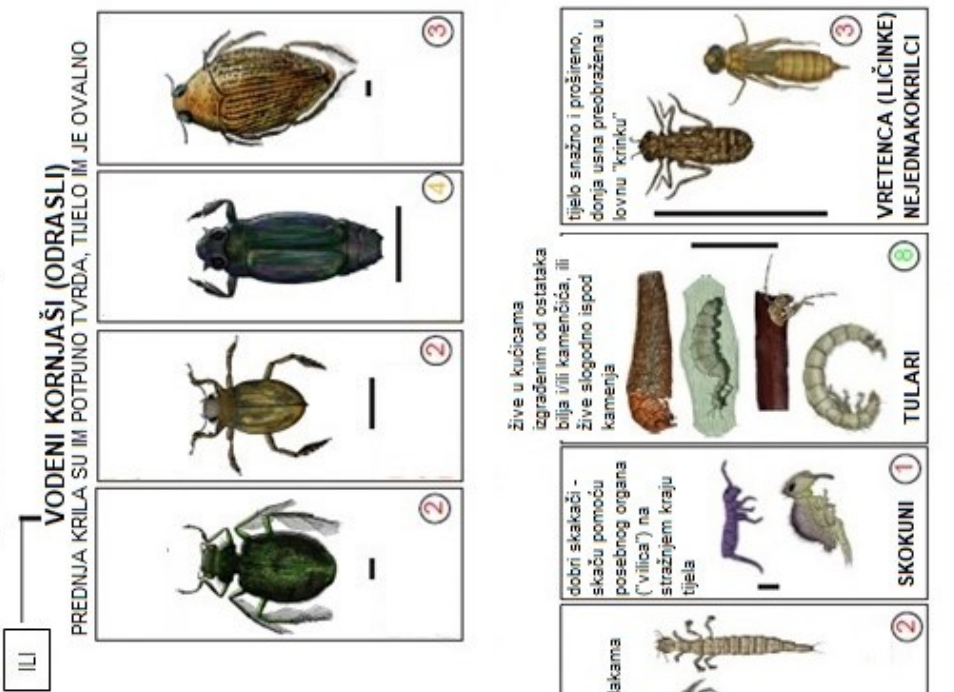

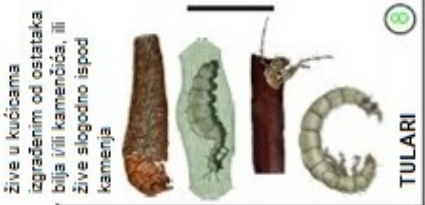
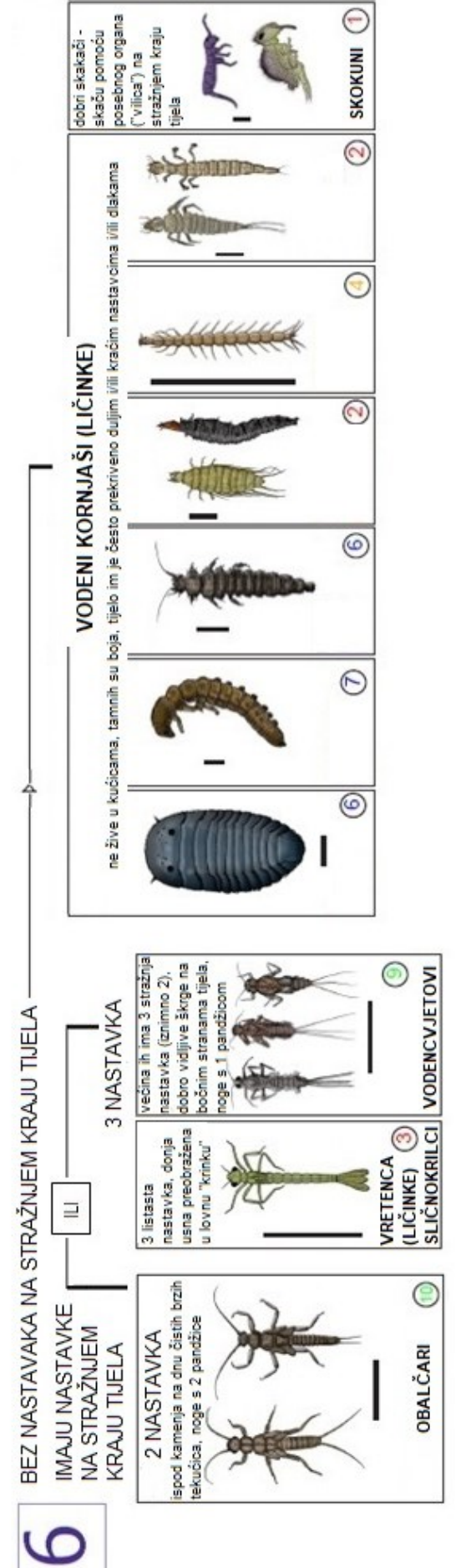

Sertić Perić, M., Radanović, I. 2017. Urbani potoci - pristupačna staništa za provedbu ekoloških istraživanja u nastavi Prirode i Biologije. Educ. biol. 3, 1, 106-126. 
Prilog 3 Pojednostavljen ključ za taksonomsko određivanje slatkovodnih organizama obraštaja (prilagođeno prema: https://sites.google.com/a/hsd.k12.or.us/water-bears-phylum-tardigrada/the-life-cycle-of-a-water-bear; http://www.sciencedirect.com/science/article/pi)

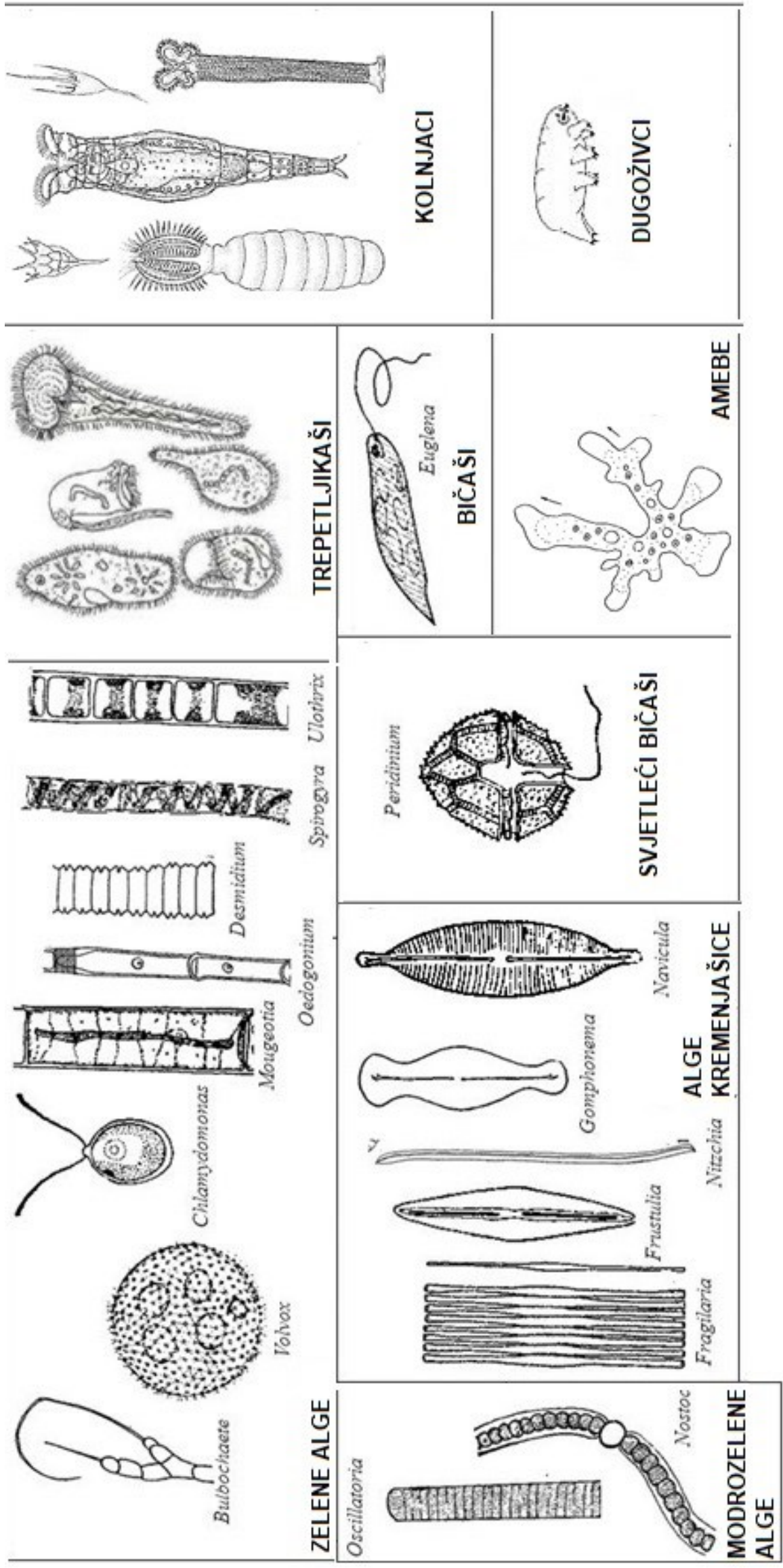

Sertić Perić, M., Radanović, I. 2017. Urbani potoci - pristupačna staništa za provedbu ekoloških istraživanja u nastavi Prirode i Biologije. Educ. biol. 3, 1, 106-126. 
Prilog 4 Slikovni ključ za slatkovodne makrobeskralježnjake uz biotički indeks prema BMWP - ASPT metodi (revidirano slijedom prema Armitage i sur, 1983; Alba-Tercedor i Sanchez-Ortega, 1988; Martin i sur, 2007 uz dopunu podataka prema istraživačkom iskustvu $\mathrm{u} \mathrm{RH}$

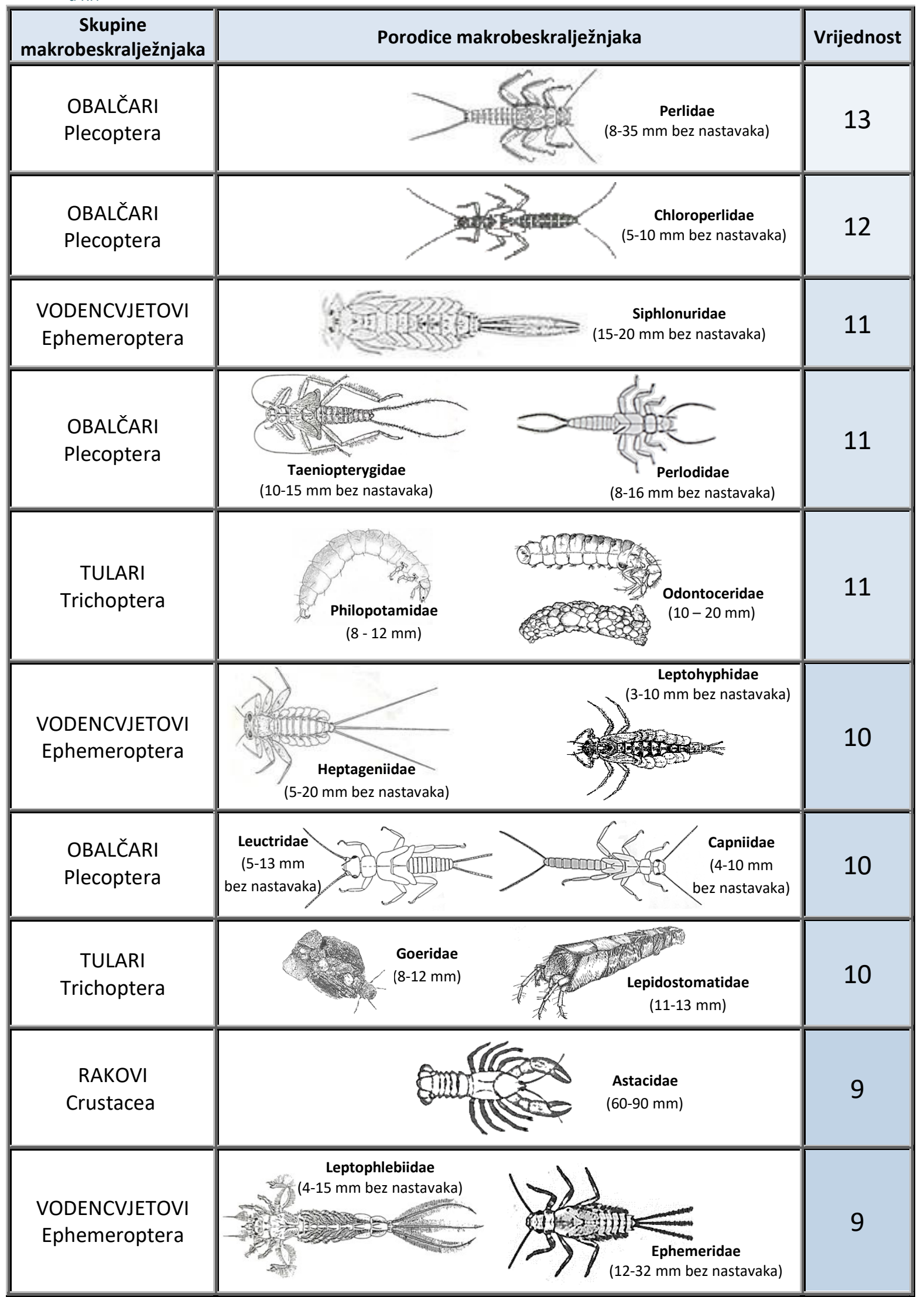

Sertić Perić, M., Radanović, I. 2017. Urbani potoci - pristupačna staništa za provedbu ekoloških istraživanja u nastavi Prirode i Biologije. Educ. biol. 3, 1, 106-126. 


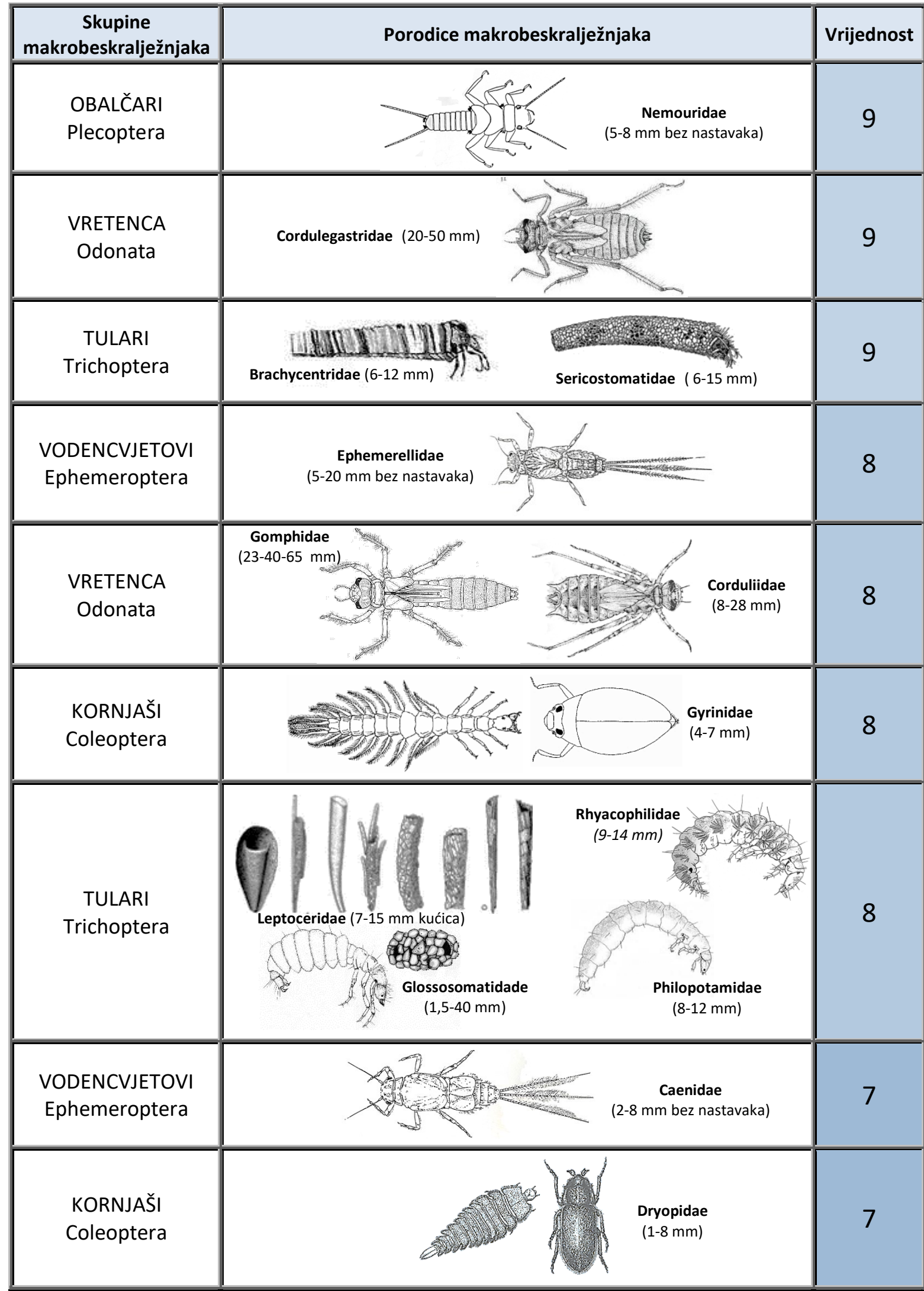

Sertić Perić, M., Radanović, I. 2017. Urbani potoci - pristupačna staništa za provedbu ekoloških istraživanja u nastavi Prirode i Biologije. Educ. biol. 3, 1, 106-126. 


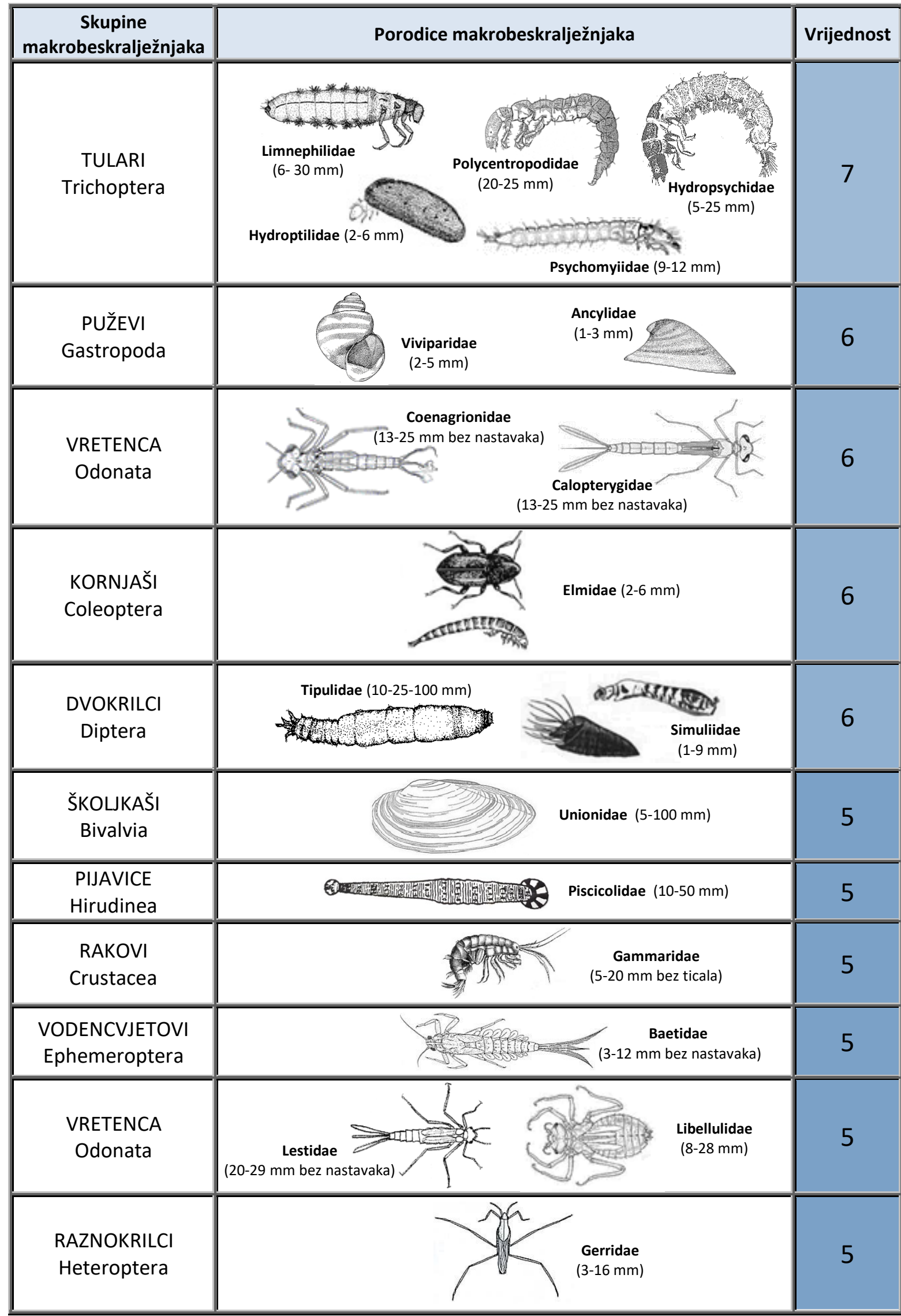

Sertić Perić, M., Radanović, I. 2017. Urbani potoci - pristupačna staništa za provedbu ekoloških istraživanja u nastavi Prirode i Biologije. Educ. biol. 3, 1, 106-126. 


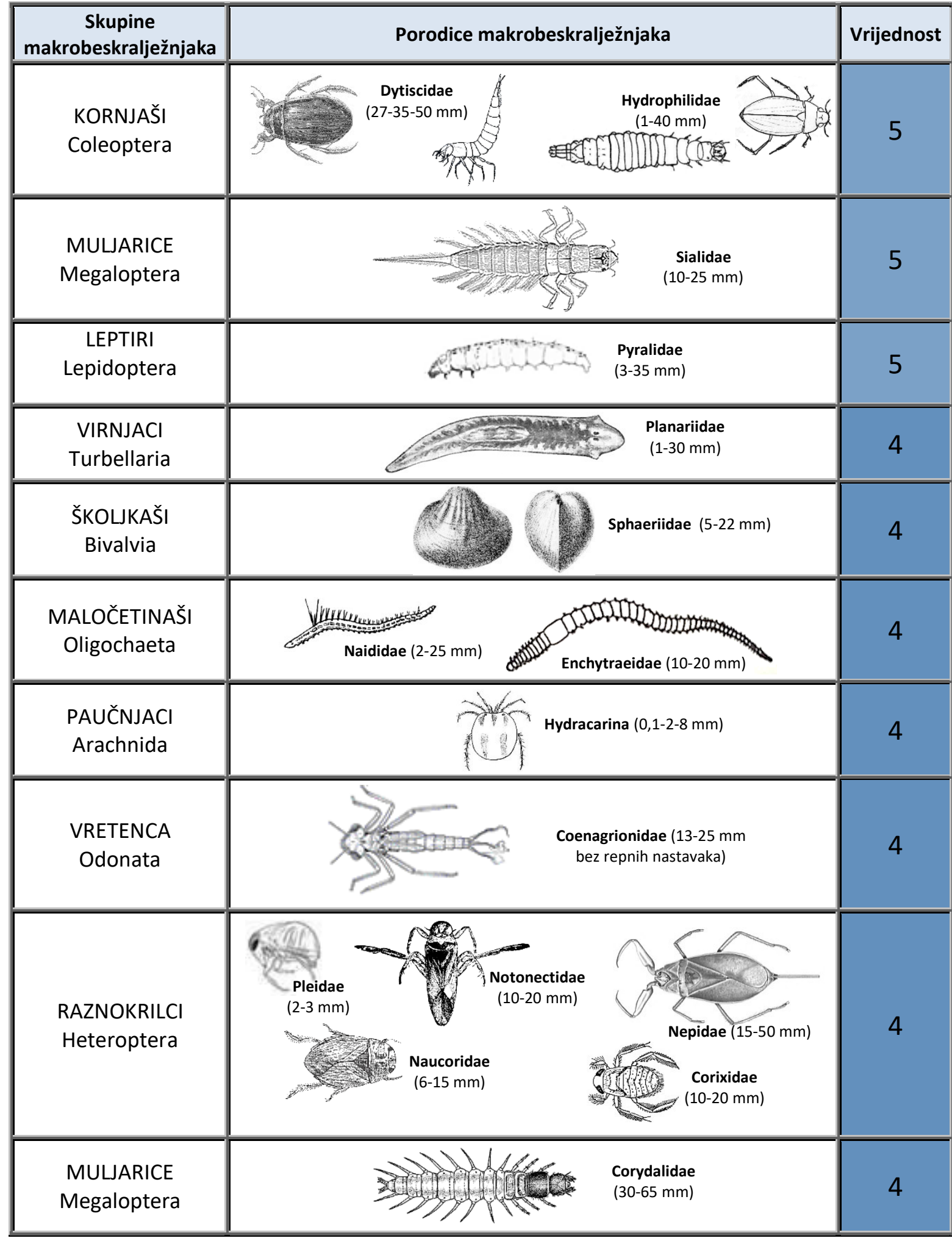




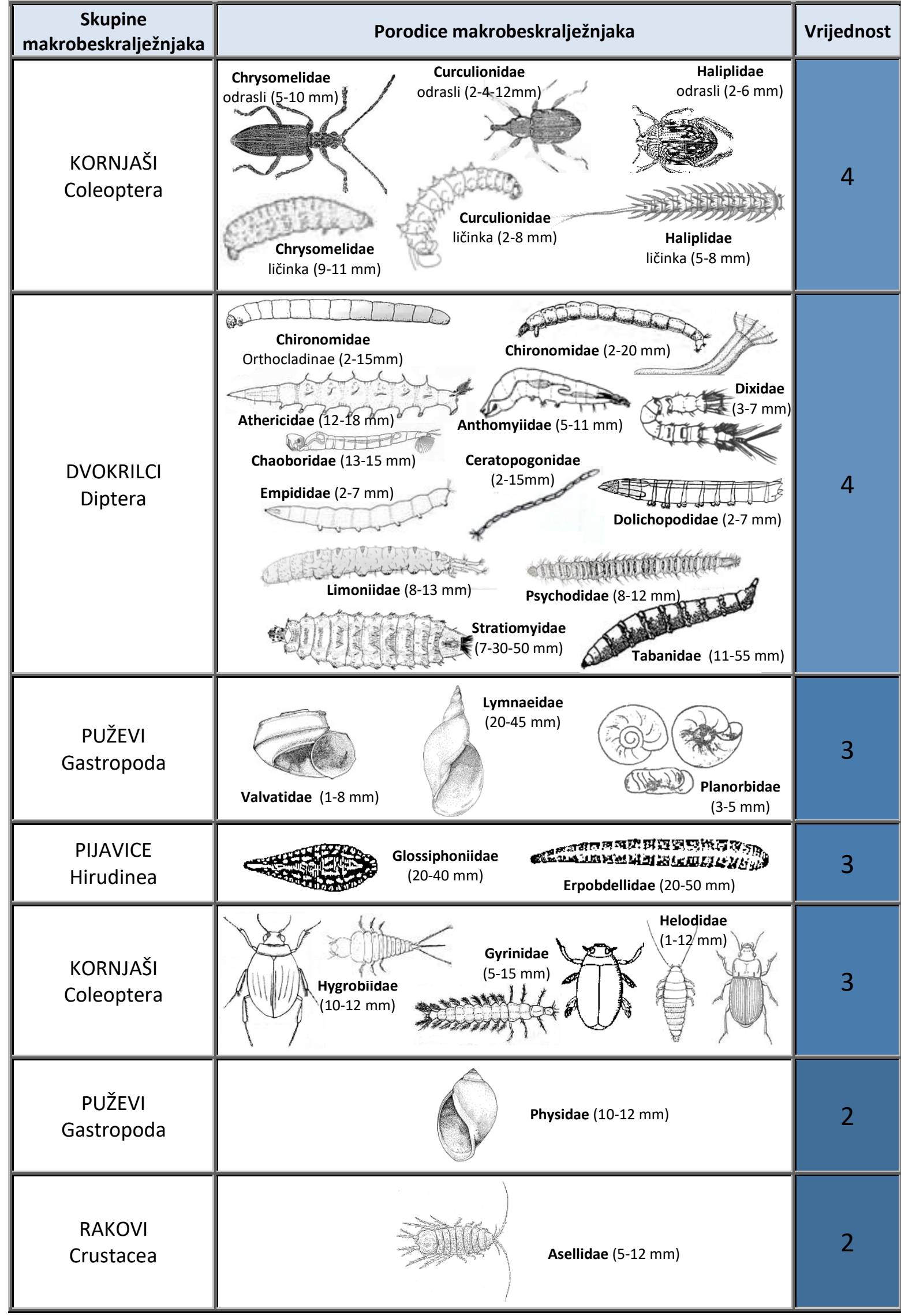

Sertić Perić, M., Radanović, I. 2017. Urbani potoci - pristupačna staništa za provedbu ekoloških istraživanja u nastavi Prirode i Biologije. Educ. biol. 3, 1, 106-126. 


\begin{tabular}{|c|c|c|}
\hline $\begin{array}{c}\text { Skupine } \\
\text { makrobeskralježnjaka }\end{array}$ & Porodice makrobeskralježnjaka & Vrijednost \\
\hline $\begin{array}{c}\text { DVOKRILCI } \\
\text { Diptera }\end{array}$ & $\begin{array}{l}\text { Chironomidae } \\
\text { Chironominae }(2-15 \mathrm{~mm})\end{array}$ & 2 \\
\hline $\begin{array}{l}\text { MALOČETINAŠI } \\
\text { Oligochaeta }\end{array}$ & $\begin{array}{l}\text { Lumbriculidae } \\
\text { Stylodrilus sp. } \\
\text { (60-80mm) }\end{array}$ & 1 \\
\hline $\begin{array}{l}\text { DVOKRILCI } \\
\text { Diptera }\end{array}$ & $\begin{array}{l}\text { Syrphidae } \\
(4-25 \mathrm{~mm})\end{array}$ & 1 \\
\hline $\begin{array}{l}\text { LEPTIRI } \\
\text { Lepidoptera }\end{array}$ & 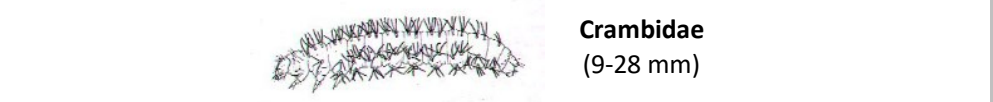 & 1 \\
\hline $\begin{array}{l}\text { PIJAVICE } \\
\text { Hirudinea }\end{array}$ & 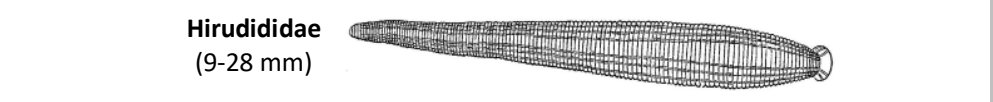 & 0 \\
\hline
\end{tabular}




\title{
URBAN STREAMS - ACCESSIBLE HABITATS FOR CONDUCTING ECOLOGICAL RESEARCH WITHIN NATURAL SCIENCE AND BIOLOGY SCHOOL CLASSES
}

\author{
Mirela Sertić Perić, Ines Radanović \\ Faculty of Science of the University of Zagreb, Department of Biology, Zagreb, Croatia \\ msertic@biol.pmf.hr
}

\begin{abstract}
By expanding urban zones and increasing the urban population, cities have become the largest source of pollution. Contemporary urban activities increase the quality of life of the city's population, and they change the natural state of the environment. Therefore, urban ecology has emerged in modern biology - one of the newer disciplines crucial for urbanism and urban planning, which enables the assessment of environmental status in cities and the implementation of systematic monitoring for the purpose of preserving and protecting urban ecosystems, including urban watercourses. In this paper we present an example of a research dealing with urban streams, i.e., exploring the scale and possible consequences of urban impacts on ecology of aquatic ecosystems and likely serving as a basis for explaining basic ecological concepts and contents such as the structure of biological communities, nutritional network, oligotrophy. Furthermore, by linking urban ecology topic with the problem of endangered water resources, and using urban streams as model habitats to explore ecological themes (and concepts) in natural science and biology school classes, pupils (besides important ecological concepts) meet the modern ideology of "green growth", "green" cities, sustainable development, environmental protection and regional development. Described study is appropriate for upper secondary school students (Biology 7 and 8) and/or secondary school students (in form of short- and/or long-term ecological survey of urban streams close to school/student environment). It includes the investigation of ecological status of urban streams through monitoring: (i) water quality (physical-chemical properties of water); (ii) the composition of aquatic fauna, which forms the basis of feeding chains in aquatic ecosystems (benthic macroinvertebrates and periphytic organisms); (iii) dynamics of transport (downstream drift) of organisms in urban watercourses; (iv) a biotic index based on observed macroinvertebrates as water contamination information. It is important to note that selected activities can be applied in exploring basic biological indicators of all - not just urban - aquatic ecosystems. In this respect, the methodology described may be adapted and applied for similar research of other types of aquatic habitats (i.e., running waters) available to students. In the implementation of the activities, it is encouraged to use the GLOBE Leaders Manual, available at http://globe.pomsk.hr/prirucnik.htm, which is already used by more than one hundred Croatian schools involved in the GLOBE network. However, we also propose newer (quantitative) sampling methods for macroinvertebrates and periphytic organisms, as well as simplified taxonomic keys for organisms to be applied in natural science and biology school classes.
\end{abstract}

Keywords: urban ecology, macroinvertebrates, drift, Hess sampler, biotic index, taxonomic determination keys

Sertić Perić, M., Radanović, I. 2017. Urbani potoci - pristupačna staništa za provedbu ekoloških istraživanja u nastavi Prirode i Biologije. Educ. biol. 3, 1, 106-126. 